\title{
Expression of proteins related to autotaxin- lysophosphatidate signaling in thyroid tumors
}

\author{
Eunah Shin ${ }^{1,2}$ and Ja Seung Koo ${ }^{1,2^{*}}$ (1)
}

\begin{abstract}
Background: We aimed to investigate the expression of proteins related with autotaxin (ATX)-lysophosphatidate (LPA) signaling and the clinical implications in primary and metastatic thyroid tumors.

Methods: We constructed tissue microarrays with 545 primary thyroid tumors [338 papillary thyroid carcinoma (PTC), 111 follicular carcinoma (FC), 69 medullary carcinoma (MC), 23 poorly differentiated carcinoma (PDC), and four anaplastic carcinoma (AC)]. Immunohistochemical stains for proteins related to ATX-LPA signaling (e.g., ATX, LPA1, LPA2, and LPA3) were performed.

Results: The expression of ATX was highest in MC, while the LPA1 expression was higher in PDC and AC, and the expression of LPA2 and LPA3 was highest in PTC $(p<0.001)$. Additionally, the expression of ATX, LPA1, and LPA2 was higher in conventional-type PTC than in follicular-variant PTC $(p<0.05)$. PTC with BRAF V600E mutation showed higher expression of ATX, LPA1, LPA2, and LPA3 than PTC without BRAF V600E mutation $(p<0.001)$. In univariate analysis, ATX positivity $(p=0.005)$ and LPA1 positivity $(p=0.014)$ were correlated with shorter overall survival in PTC.

Conclusion: Proteins related to the ATX-LPA axis showed different levels of expression in primary thyroid tumors according to subtype.
\end{abstract}

Keywords: Autotaxin, Lysophosphatidate, Thyroid, Tumor

\section{Background}

Autotaxin (ATX) is a glycoprotein transcribed by the ENPP2 gene on chromosome 8 [1]. ATX is the same molecule as lysophospholipase D and converts lysophosphatidylcholine (LPC) to bioactive lipid mediator lysophosphatidate (LPA). LPA, after binding to the appropriate receptor, activates phospholipase $\mathrm{C}$ and the MAPK, PI3K, and RhoA pathways and is involved in various cellular processes [2, 3]. LPA receptor is a G-protein-coupled receptor. There are at least six LPA receptors, LPA1 through LPA6. LPA1 through LPA3 belong to the EGD family (i.e., LPA1-EDG2, LPA2-EDG4, LPA3EDG7), while LPA4 through LPA6 are similar to the P2Y nucleotide receptor [4]. This ATX-LPA signaling is

\footnotetext{
*Correspondence: kjs1976@yuhs.ac

${ }^{2}$ Department of Pathology, Yonsei University College of Medicine, Severance Hospital, 50 Yonsei-ro, Seodaemun-gu, Seoul 120-752, South Korea

Full list of author information is available at the end of the article
}

involved in tumor formation, progression, and metastasis $[5,6]$.

Thyroid cancer is a relatively common malignancy, affecting about $1 \%$ of the population. The most common histologic type of thyroid cancer is papillary thyroid carcinoma (PTC), followed by follicular carcinoma (FC), medullary carcinoma (MC), poorly differentiated carcinoma (PDC), and anaplastic carcinoma (AC). These histologic subtypes of thyroid cancer are known to have different cell origins, clinical manifestations, metastatic patterns, and clinical prognoses. Previously, ATX has been reported to be highly expressed in undifferentiated carcinoma [7], and it is also indicated to be expressed in follicular carcinoma [8]. Furthermore, as ATX expression is higher in thyroid cancer than in benign lesion [9] and is correlated with prognostic factors in thyroid cancer [10], ATX-LPA signaling is likely to have an influence on thyroid cancer biology. However, studies on proteins related to ATX-LPA signaling in recurrent and metastatic thyroid cancer and according to thyroid tumor subtype have 
not been reported. Thus, we aimed to assess the expression of proteins related to ATX-LPA signaling in recurrent and metastatic thyroid cancer and according to thyroid tumor subtype.

\section{Materials and methods}

\section{Patient selection and histologic evaluation}

Patients diagnosed with PTC who underwent surgery between January 2012 and December 2013 at Severance Hospital, Sinchon-dong, South Korea, were included in the study. As for the remaining subtypes, patients who underwent surgery between January 2000 and December 2014 at Severance Hospital were included. Those who had received preoperative chemotherapy were excluded. This study was approved by the Institutional Review Board of Yonsei University Severance Hospital. Hematoxylin-and-eosin-stained slides of all cases were retrospectively reviewed by a thyroid pathologist (Koo, JS). Clinicopathologic data were obtained from the patients' medical records and included age at diagnosis, disease recurrence, metastasis, current status, and length of follow-up. Tumor size, location (right or left lobe), extent (confined to the thyroid parenchyme or with extrathyroidal spread), and number of metastatic lymph nodes were also noted from a review of the slides and the surgical pathology reports.

Tumor stroma of PTC was classified as follows: desmoplastic type, tumor stroma composed of cellular fibroblast/myofibroblast proliferation; sclerotic type, tumor stroma composed of collagenous component with few cellular components; pauci type, near absence of a stromal reaction; or inflammatory type, tumor stroma composed of inflammatory cells such as lymphocytes.

\section{Tissue microarray}

A representative area showing tumor and tumor stroma was selected on a hematoxylin-and-eosin-stained slide, and a corresponding spot was marked on the surface of the paraffin block. Using a biopsy needle, the selected area was punched out, and a 3-mm tissue core was transferred to a $6 \times 5$ recipient block. Two tissue cores from the invasive tumors were extracted to minimize extraction bias. Each tissue core was assigned a unique tissue microarray location number that was linked to a database containing other clinicopathologic data.

\section{Immunohistochemistry}

The antibodies used for immunohistochemistry in this study are shown in Table 1. Formalin-fixed, paraffinembedded tissue sections were used for immunohistochemistry. During the experiments, $3-\mu \mathrm{m}$-thick tissue sections were deparaffinized and rehydrated in xylene and graded alcohol. We used the Ventana Discovery XT automated stainer (Ventana Medical Systems, Tucson, AZ, USA). Cell Conditioning 1 buffer (citrate buffer, pH: 6.0; Ventana Medical Systems, Tucson, AZ, USA) was used for antigen retrieval. Appropriate positive and negative controls were used for each antibody.

\section{Interpretation of immunohistochemical staining}

Immunohistochemical markers were assessed by light microscopy. All stained slides were semi-quantitatively

Table 1 Expression of ATX-LPA axis-related proteins according to the histologic subtype of thyroid cancer

\begin{tabular}{|c|c|c|c|c|c|c|c|}
\hline Parameters & $\begin{array}{l}\text { Total } \\
\mathrm{n}=545(\%)\end{array}$ & $\begin{array}{l}\text { PTC } \\
n=338(\%)\end{array}$ & $\begin{array}{l}\mathrm{FC} \\
\mathrm{n}=111(\%)\end{array}$ & $\begin{array}{l}M C \\
n=69(\%)\end{array}$ & $\begin{array}{l}\text { PDC } \\
n=23(\%)\end{array}$ & $\begin{array}{l}A C \\
n=4(\%)\end{array}$ & $p$-value \\
\hline ATX & & & & & & & $<0.001$ \\
\hline Negative & $368(67.5)$ & $220(65.1)$ & $102(91.9)$ & $22(31.9)$ & $21(91.3)$ & $3(75.0)$ & \\
\hline Positive & $177(32.5)$ & $118(34.9)$ & $9(8.1)$ & $47(68.1)$ & $2(8.7)$ & $1(25.0)$ & \\
\hline LPA 1 & & & & & & & $<0.001$ \\
\hline Negative & $292(53.6)$ & $169(50.0)$ & 73 (65.8) & 44 (63.8) & $5(21.7)$ & $1(25.0)$ & \\
\hline Positive & $253(46.4)$ & $169(50.0)$ & $38(34.2)$ & $25(36.2)$ & 18 (78.3) & $3(75.0)$ & \\
\hline LPA1 (S) & & & & & & & 0.051 \\
\hline Negative & $530(97.2)$ & $323(95.6)$ & $111(100.0)$ & $69(100.0)$ & $23(100.0)$ & $4(100.0)$ & \\
\hline Positive & $15(2.8)$ & $15(4.4)$ & $0(0.0)$ & $0(0.0)$ & $0(0.0)$ & $0(0.0)$ & \\
\hline LPA2 & & & & & & & $<0.001$ \\
\hline Negative & $365(67.0)$ & $191(56.5)$ & 85 (76.6) & $69(100.0)$ & $16(69.6)$ & $4(100.0)$ & \\
\hline Positive & $180(33.0)$ & $147(43.5)$ & $26(23.4)$ & $0(0.0)$ & 7 (30.4) & $0(0.0)$ & \\
\hline LPA3 & & & & & & & $<0.001$ \\
\hline Negative & $189(34.7)$ & $56(16.6)$ & $52(46.8)$ & $67(97.1)$ & $10(43.5)$ & $4(100.0)$ & \\
\hline Positive & $356(65.3)$ & $282(83.4)$ & $59(53.2)$ & $2(2.9)$ & $13(56.5)$ & $0(0.0)$ & \\
\hline
\end{tabular}

Italic values represent significance of $\mathrm{p}$-value $(\mathrm{p}<0.05)$

PTC papillary thyroid carcinoma, FC follicular carcinoma, MC medullary carcinoma, $P D C$ poorly differentiated carcinoma, $A C$ anaplastic carcinoma 
evaluated [11]. Tumor and stromal cell staining was assessed as 0: negative or weak immunostaining in $<1 \%$ of the tumor/stroma; 1 : focal expression in $1 \%$ to $10 \%$ of the tumor/stroma; 2 : positive in $11 \%$ to $50 \%$ of the tumor/ stroma; or 3: positive in $51 \%$ to $100 \%$ of the tumor/ stroma. Entire tumor areas included in the TMA were evaluated in all cases; a grade of 0 was considered negative and grades of 1 to 3 were considered positive.

\section{Statistical analysis}

Data were analyzed using Statistical Package for the Social Sciences for Windows, version 23.0 (SPSS Inc., Chicago, IL, USA). For determination of statistical significance, Student's $t$ test and Fisher's exact test were used for continuous and categorical variables, respectively. When analyzing data with multiple comparisons, a corrected p-value with application of the Bonferroni multiple comparison procedure was used. Statistical significance was set at $\mathrm{p}<0.05$. Kaplan-Meier survival curves and log-rank statistics were employed to evaluate the time to tumor recurrence and overall survival. Multivariate regression analysis was performed using the Cox proportional hazards model.

\section{Results}

\section{Basal characteristics of thyroid cancer}

All retrieved cases were subject to this study, consisting of 338 cases of PTC, 111 cases of FC, 69 cases of MC, 23 cases of PDC, and four cases of AC. Basal characteristics of PTC are listed in Additional file 1: Table S3. PTC cases were composed of 302 conventional type and 36 follicular variant, and 236 cases of PTC (69.8\%) had BRAF V600E mutation. FC consisted of 61 cases of minimally invasive type, 37 cases of encapsulated angioinvasive type, and 13 cases of widely invasive type (Additional file 1: Table S3). Basal characteristics of $\mathrm{MC}, \mathrm{PDC}$, and $\mathrm{AC}$ are listed in Additional file 1: Table S3.

\section{Expression of proteins related to the ATX-LPA axis in thyroid cancer}

The expression of proteins related to the ATX-LPA axis in thyroid cancer showed differences in ATX, LPA1, LPA2, and LPA3 $(\mathrm{p}<0.001)$. ATX was most highly expressed in medullary carcinoma, while LPA1 was predominant in PDC and AC, and LPA2 and LPA3 were predominant in PTC (Table 1 and Fig. 1).

When assessed according to the histologic subtype and BRAF V600E mutation status, ATX $(p=0.002)$, LPA1 $(\mathrm{p}=0.014)$, and LPA2 $(\mathrm{p}=0.001)$ expression was different according to the histologic subtype, and the expression of ATX, LPA1, LPA2 and LPA3 $(\mathrm{p}<0.001)$ was different according to BRAF V600E mutation status. ATX, LPA1, and LPA2 expression was higher in conventional type than in FVPTC, while PTC with BRAF V600E mutation showed higher expression of ATX, LPA1, LPA2, and LPA3 than did PTC without BRAF V600E mutation (Table 2 and Fig. 2).

In FC cases, expression of LPA1 was highest in minimally invasive type $(\mathrm{p}=0.004$, Table 3$)$. In PTC cases, a statistically significant positive correlation between proteins related to the ATX-LPA axis was shown in the following: LPA1 and ATX $(\mathrm{r}=0.434, \mathrm{p}<0.001)$, LPA1 $(\mathrm{S})$ and LPA1 $(\mathrm{r}=0.187, \mathrm{p}=0.001)$, LPA2 and ATX $(r=0.459, p<0.001)$, LPA2 and LPA1 $(r=0.591$, $\mathrm{p}<0.001)$, LPA 2 and LPA $1(\mathrm{~S})(\mathrm{r}=0.188, \mathrm{p}=0.001)$, LPA3 and ATX $(r=0.193, p<0.001)$, LPA3 and LPA $1(r=0.318$, $\mathrm{p}<0.001)$, and LPA3 and LPA2 $(\mathrm{r}=0.295, \mathrm{p}<0.001)$ (Table 4).

\section{Correlations between clinicopathologic factors and expression of proteins related to the ATX-LPA axis in thyroid cancer}

When correlations between the expression of proteins related to the ATX-LPA axis and clinicopathologic factors were analyzed, LPA2 expression was different according to the stromal type $(\mathrm{p}=0.009)$ in PTC, and LPA1 expression was different according to the vascular invasion status in FC $(\mathrm{p}<0.001)$. In PTC, desmoplastic type showed high expression of LPA2. LPA1 negativity was correlated with vascular invasion in FC (Fig. 3).

\section{Impact of the expression of proteins related to the ATX- LPA axis on prognosis of thyroid cancer}

The impact of expression of proteins related to the ATXLPA axis on the prognosis of thyroid cancer was analyzed. As a result, ATX positivity $(\mathrm{p}=0.005)$ and LPA1 positivity $(\mathrm{p}=0.014)$ were two factors that demonstrated correlation with shorter overall survival (Table 5 and Fig. 4) in univariate analysis. Multivariate Cox analysis showed that lymph node metastasis (hazard ratio: 5.978, 95\% confidence interval (CI) 1.339-26.69; $\mathrm{p}=0.019$ ) was an independent factor associated with shorter DFS, while age ( $\geq 45$ years) (hazard ratio: 16.39 , 95\% CI 2.129-126.2; $\mathrm{p}=0.007$ ) was an independent factor associated with shorter OS (Table 6).

\section{Discussion}

We investigated the expression of proteins related to the ATX-LPA axis in thyroid cancer. First, ATX was more highly expressed in medullary carcinoma than in other subtypes. Previous studies have shown that ATXrelated protein expression was higher in thyroid cancer or metastatic thyroid cancer than in normal thyroid tissue or benign thyroid neoplasm $[9,10]$, but there has not been any report published to date on ATX-related protein expression in thyroid medullary carcinoma. 


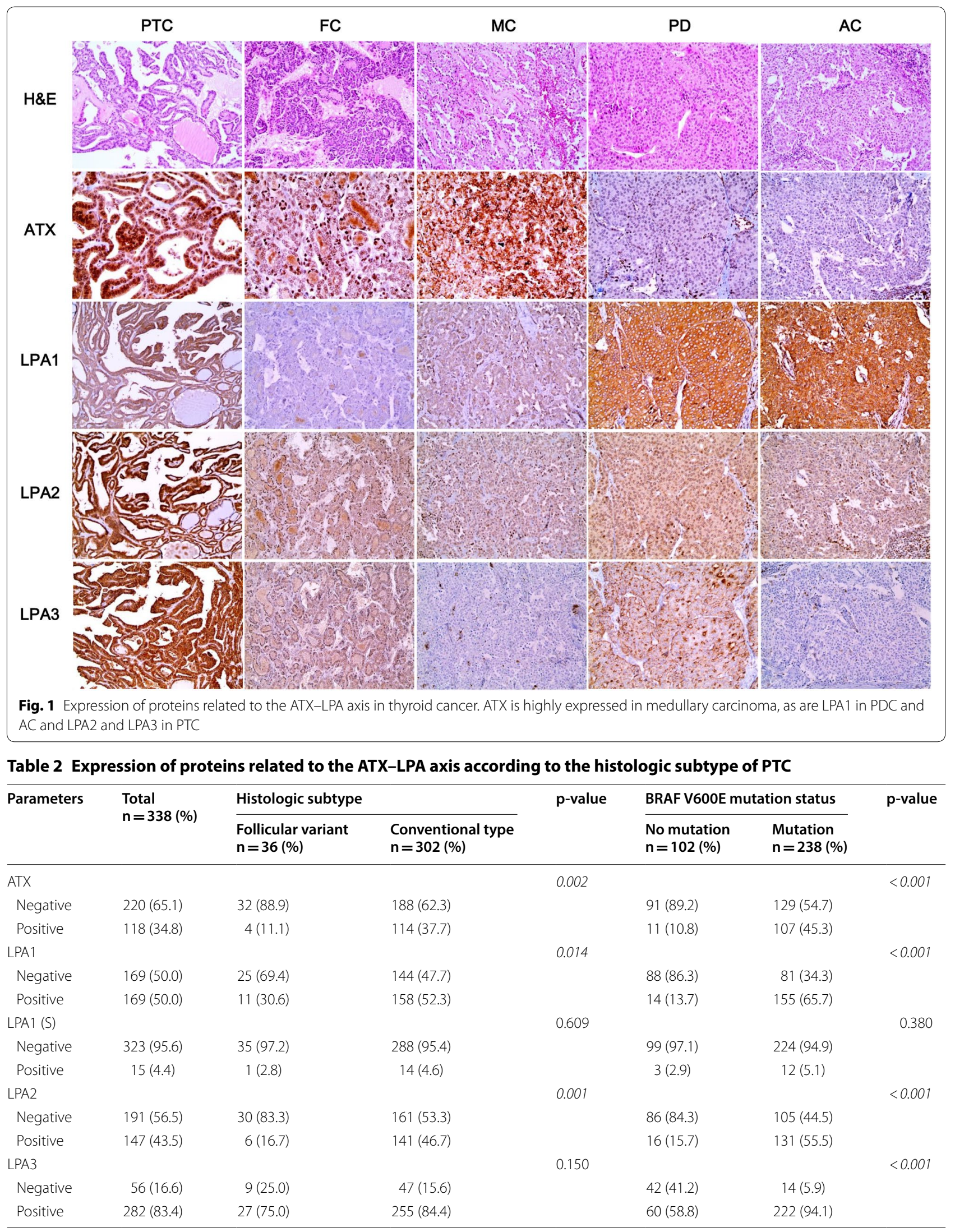




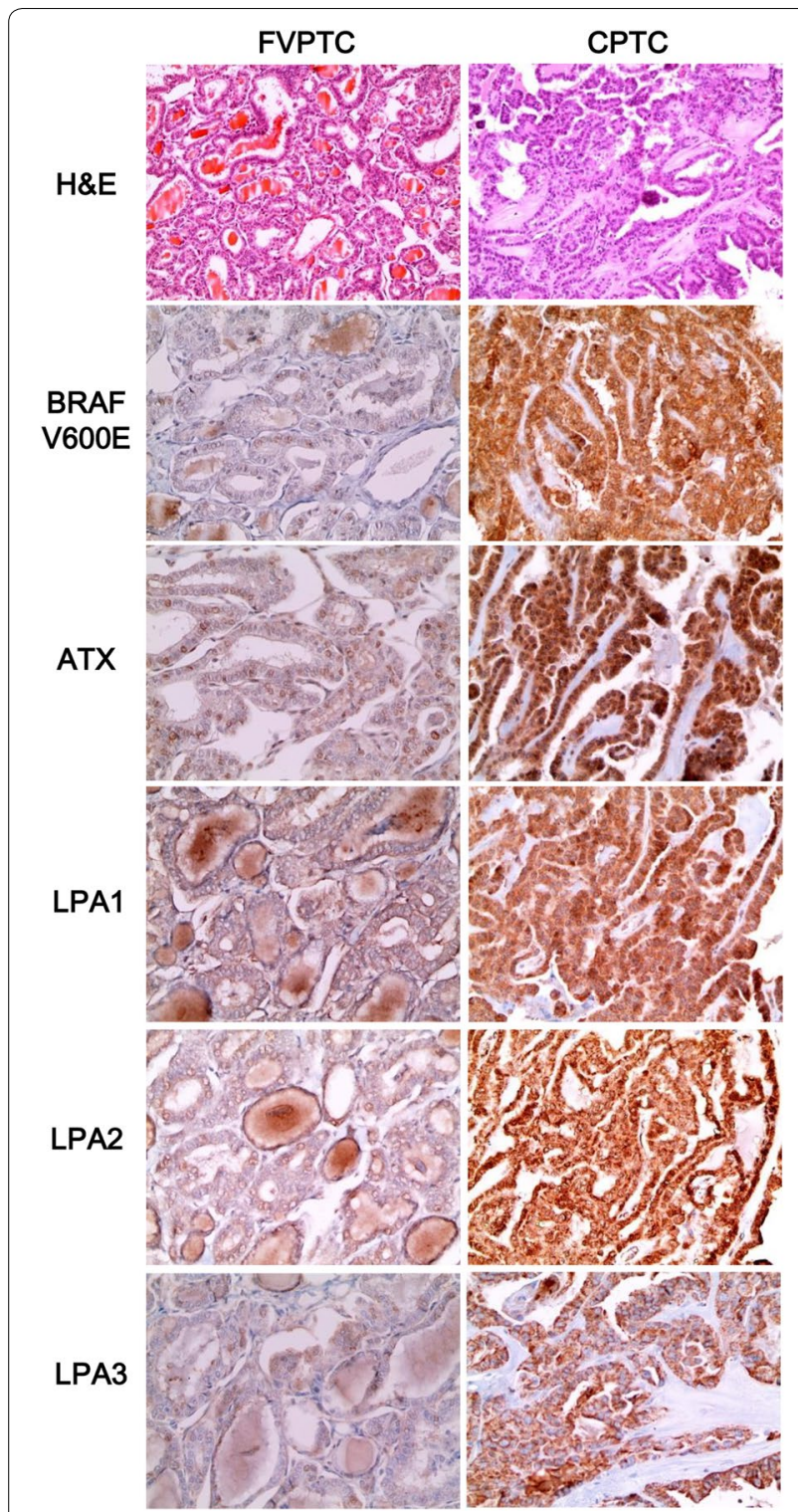

Fig. 2 Expression of proteins related to ATX-LPA axis in TPC. ATX, LPA1, LPA2, and LPA3 expression is higher in conventional-type PTC than in FVPTC, and PTC with BRAF V600E mutation shows higher expression of those than does PTC without BRAF V600E mutation

The possible mechanism for the high expression of ATX in thyroid medullary carcinoma is the JAK/ STAT3 pathway. In previous studies on breast cancer, activation of the JAK/STAT3 pathway was reported to increase the expression of ATX [12], which is suggested to represent a putative STAT3 target gene. Meanwhile, it has been reported that the JAK/STAT3 pathway is also activated in thyroid medullary carcinoma [13, 14]; consequently, it is only plausible that ATX expression is somehow associated with the JAK/STAT3 pathway. Our study showed that LPA1 was highly expressed in
Table 3 Expression of proteins related to the ATX-LPA axis according to histologic subtype of FC

\begin{tabular}{|c|c|c|c|c|c|}
\hline Parameters & $\begin{array}{l}\text { Total } \\
\mathrm{n}=111 \\
(\%)\end{array}$ & $\begin{array}{l}\text { Minimally } \\
\text { invasive } \\
\text { type } \\
n=61(\%)\end{array}$ & $\begin{array}{l}\text { Encapsulated } \\
\text { angioinvasive } \\
\text { type } \\
n=37(\%)\end{array}$ & $\begin{array}{l}\text { Widely } \\
\text { invasive } \\
\text { type } \\
n=13(\%)\end{array}$ & p-value \\
\hline ATX & & & & & 0.296 \\
\hline Negative & 102 (91.9) & $54(88.5)$ & 35 (94.6) & $13(100.0)$ & \\
\hline Positive & $9(8.1)$ & $7(11.5)$ & $2(5.4)$ & $0(0.0)$ & \\
\hline LPA1 & & & & & 0.004 \\
\hline Negative & $73(65.8)$ & $32(52.5)$ & $31(83.8)$ & $10(76.9)$ & \\
\hline Positive & $38(34.2)$ & $29(47.5)$ & $6(16.2)$ & $3(23.1)$ & \\
\hline LPA2 & & & & & 0.987 \\
\hline Negative & 85 (76.6) & $47(77.0)$ & $28(75.7)$ & $10(76.9)$ & \\
\hline Positive & $26(23.4)$ & $14(23.0)$ & $9(24.3)$ & $3(23.1)$ & \\
\hline LPA3 & & & & & 0.792 \\
\hline Negative & $52(46.8)$ & $27(44.3)$ & $19(51.4)$ & $6(46.2)$ & \\
\hline Positive & $59(53.2)$ & $34(55.7)$ & $18(48.6)$ & $7(53.8)$ & \\
\hline
\end{tabular}

Italic values represent significance of $p$-value $(p<0.05)$

Table 4 Correlation among the expression of proteins related to the ATX-LPA axis in PTC

\begin{tabular}{lrrrr}
\hline Parameters & ATX & LPA1 & LPA1 (S) & LPA2 \\
\hline LPA1 & & & & \\
Correlation coefficient & 0.434 & & & \\
p-value & $<0.001$ & & & \\
LPA1 (S) & & & & \\
Correlation coefficient & 0.053 & 0.187 & & \\
p-value & 0.330 & 0.001 & & \\
LPA2 & & & & \\
Correlation coefficient & 0.459 & 0.591 & 0.188 & \\
p-value & $<0.001$ & $<0.001$ & 0.001 & \\
LPA3 & & & & \\
Correlation coefficient & 0.193 & 0.318 & 0.019 & 0.295 \\
p-value & $<0.001$ & $<0.001$ & 0.731 & $<0.001$ \\
\hline
\end{tabular}

Italic values represent significance of $p$-value $(p<0.05)$

PDC and AC, and that LPA2 and LPA3 were similarly highly expressed in PTC. A previous study on thyroid cancer reported that LPA1 messenger RNA expression showed no difference among normal thyroid tissue, benign thyroid nodule, and thyroid cancer [15]. However, the study had included PTC and FC for thyroid cancer; therefore, its direct comparison with our study, which includes PDC and AC in addition to PTC and FC for thyroid cancer, is not possible. Separately, another previous study suggested CD97 as a dedifferentiation marker in thyroid cancer [16], the expression of which is reported to be correlated with LPA receptor in thyroid cancer [17]. Such a result is related with the high expression of LPA1 in PDC and AC in our study. LPA2 

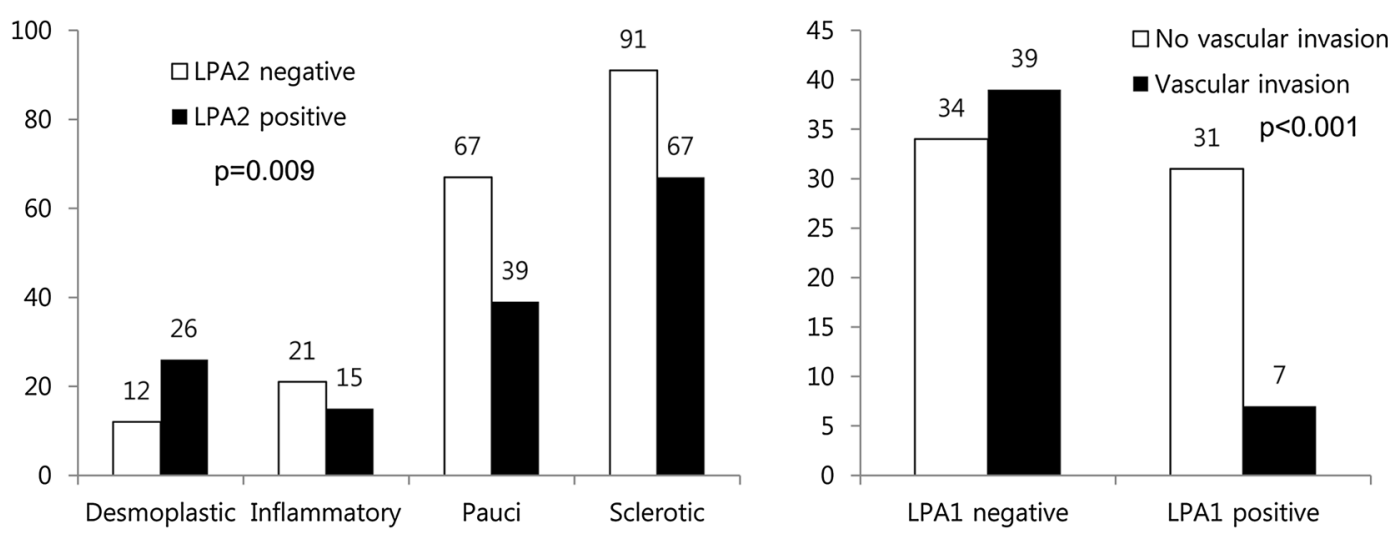

Fig. 3 Correlations between the clinicopathologic factors and the expression of proteins related to the ATX-LPA axis in thyroid cancer. When assessed according to tumor stomal type, desmoplastic type PTC shows high expression of LPA2. In FC, vascular invasion is correlated with LPA1 negativity

Table 5 Univariate analysis of the influence of the expression of proteins related to the ATX-LPA axis in thyroid papillary cancer on disease-free and overall survival by the log-rank test

\begin{tabular}{|c|c|c|c|c|c|}
\hline \multirow[t]{2}{*}{ Parameter } & \multirow{2}{*}{$\begin{array}{l}\text { Number of patients/ } \\
\text { recurrence/death }\end{array}$} & \multicolumn{2}{|l|}{ Disease-free survival } & \multicolumn{2}{|l|}{ Overall survival } \\
\hline & & $\begin{array}{l}\text { Mean survival }(95 \% \mathrm{Cl}) \\
\text { months }\end{array}$ & p-value & $\begin{array}{l}\text { Mean survival }(95 \% \mathrm{Cl}) \\
\text { months }\end{array}$ & p-value \\
\hline ATX & & & 0.894 & & 0.050 \\
\hline Negative & $220 / 12 / 8$ & 106 (103-109) & & $109(107-111)$ & \\
\hline Positive & $118 / 6 / 10$ & $104(101-108)$ & & $102(98-106)$ & \\
\hline LPA 1 & & & 0.670 & & 0.014 \\
\hline Negative & $169 / 10 / 4$ & $106(103-109)$ & & $110(109-112)$ & \\
\hline Positive & $169 / 8 / 14$ & $107(104-110)$ & & $105(101-108)$ & \\
\hline LPA1 (S) & & & 0.156 & & 0.909 \\
\hline Negative & $323 / 16 / 17$ & $107(105-109)$ & & 108 (106-109) & \\
\hline Positive & $15 / 2 / 1$ & $96(79-113)$ & & $102(89-116)$ & \\
\hline LPA2 & & & 0.947 & & 0.316 \\
\hline Negative & 191/10/8 & $107(104-110)$ & & $108(106-111)$ & \\
\hline Positive & $147 / 8 / 10$ & $106(103-110)$ & & $106(103-110)$ & \\
\hline LPA3 & & & 0.209 & & 0.204 \\
\hline Negative & $56 / 1 / 1$ & $108(104-111)$ & & $108(106-111)$ & \\
\hline Positive & $282 / 17 / 17$ & 106 (103-109) & & 107 (105-109) & \\
\hline
\end{tabular}

Italic values represent significance of $p$-value $(p<0.05)$

has been previously reported to be highly expressed in PTC, which is in concordance with our results [15]. On the other hand, our study showed low expression of proteins related to the ATX-LPA axis in PTC and FVPTC without BRAF V600E mutation, a result that disagreed with those of the previous study that reported that ATX protein expression is not correlated with BRAF mutation status [9]. Usually, most FVPTC cases do not harbor BRAF V600E mutation; thus, it is necessary to assess the correlation between BRAF V600E mutation and the ATX-LPA axis. The most plausible mechanism is that BRAF V600E mutation activates cytokine release, which in turn increases ATX protein expression. Tumor cells showing BRAF V600E mutation tend to have increased cytokine secretion such as that of interleukin (IL)-1 $\beta$, IL-6, and IL-8 [18], because cytokines such as tumor necrosis factor alpha or IL-1 $\beta$ increase ATX and LPA levels. In our study, ATX and LPA1 expression was a poor prognosis factor in PTC, which is in concordance with previous study results that had identified ATX as a poor prognosis factor in breast cancer [19] and in prostate cancer [20] and, separately, LPA2 as a poor prognosis factor in breast cancer [21]. 

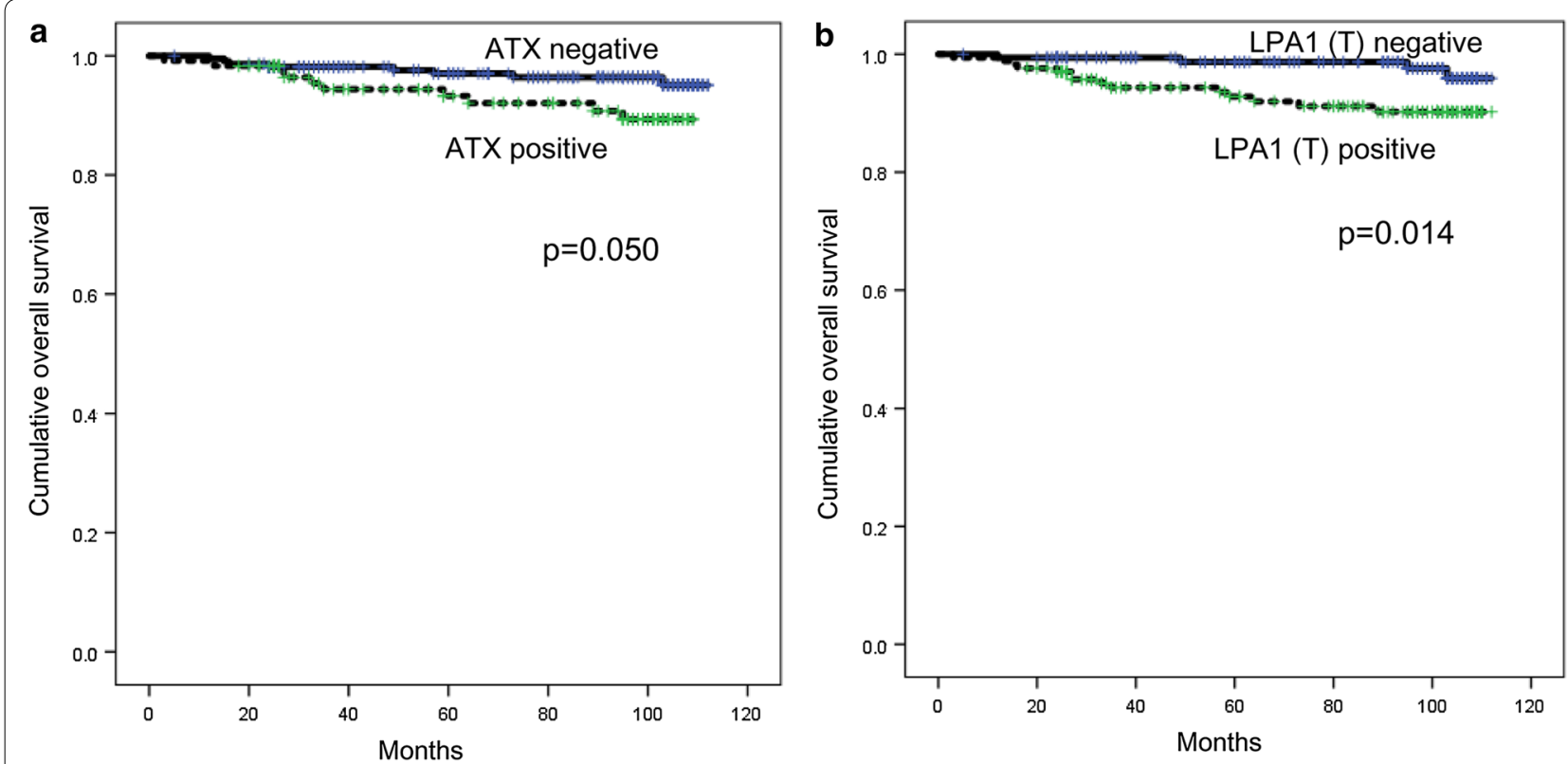

Fig. 4 The impact of the expression of proteins related to the ATX-LPA axis on prognosis in thyroid papillary carcinoma. In univariate analysis, factors that are correlated with shorter overall survival in PTC are ATX positivity $\mathbf{a}$ and LPA1 positivity $\mathbf{b}$

Table 6 Multivariate analysis of factors influencing survival of patients with PTC

\begin{tabular}{|c|c|c|c|c|c|c|}
\hline \multirow[t]{2}{*}{ Included parameters } & \multicolumn{3}{|c|}{ Disease-free survival } & \multicolumn{3}{|c|}{ Overall survival } \\
\hline & Hazard ratio & $95 \% \mathrm{Cl}$ & p-value & Hazard ratio & $95 \% \mathrm{Cl}$ & p-value \\
\hline Age (years) & & & 0.617 & & & 0.007 \\
\hline$<45$ versus $\geq 45$ & 1.282 & $0.485-3.389$ & & 16.39 & $2.129-126.2$ & \\
\hline Sex & & & 0.508 & & & 0.925 \\
\hline Male versus female & 0.700 & $0.244-2.011$ & & 1.065 & $0.290-3.915$ & \\
\hline Tumor size $(\mathrm{cm})$ & & & 0.816 & & & 0.188 \\
\hline$\leq 2.0$ versus $>2.0$ & 1.134 & $1.134-3.268$ & & 2.005 & $0.711-5.653$ & \\
\hline Tumor extension & & & 0.378 & & & 0.440 \\
\hline Intrathyroidal versus extrathyroidal & 0.641 & $0.239-1.722$ & & 0.647 & $0.214-1.955$ & \\
\hline LN metastasis & & & 0.019 & & & 0.064 \\
\hline No versus yes & 5.978 & $1.339-26.69$ & & 2.940 & $0.939-9.202$ & \\
\hline ATX & & & 0.997 & & & 0.360 \\
\hline Negative versus positive & 0.998 & $0.334-2.981$ & & 1.633 & $0.571-4.665$ & \\
\hline LPA1 & & & 0.688 & & & 0.252 \\
\hline Negative versus positive & 0.805 & $0.278-2.327$ & & 2.093 & $0.592-7.403$ & \\
\hline
\end{tabular}

Italic values represent significance of $p$-value $(p<0.05)$

The clinical implication of our study is that the ATX-LPA signaling axis may be a possible therapeutic target in thyroid cancer. Ki16425, a nonlipid competitive inhibitor of LPA1 and LPA3, actually suppressed bone metastasis in a mouse model [22]. Debio0719, an R-stereoisomer of Ki16425, was found to inhibit distant metastasis [23, 24]. BrP-LPA, which is a dual ATX and
pan-LPAR inhibitor, inhibited cell migration and invasion [25]. In addition, an ATX inhibitor, ONO-843050, decreased tumor volume to $50 \%$ to $60 \%$ in a mouse model of PTC [9]. Therefore, the ATX-LPA axis may be an effective treatment target for thyroid cancer, and further clinical trials are necessary. 


\section{Conclusion}

The expression of proteins related to the ATX-LPA axis is different according to tumor subtype and is notably higher in metastatic thyroid cancer than in primary tumor. Furthermore, proteins related to the ATX-LPA axis may represent candidates for effective treatment target in thyroid cancer.

\section{Supplementary information}

Supplementary information accompanies this paper at https://doi. org/10.1186/s12967-019-2028-7.

Additional file 1. Additional tables.

\section{Abbreviations}

ATX: autotaxin; LPC: Iysophosphatidylcholine; LPA: lysophosphatidate; PTC: papillary thyroid carcinoma; FC: follicular carcinoma; MC: medullary carcinoma; PDC: poorly differentiated carcinoma; AC: anaplastic carcinoma.

\section{Acknowledgements}

Not applicable.

\section{Authors' contributions}

ES participated in the design of the study and performed the statistical analysis and carried out the immunoassays. JSK conceived the study, and participated in its design and coordination and helped to draft the manuscript. Both authors read and approved the final manuscript.

\section{Funding}

This study was supported by a grant from the National R\&D Program for Cancer Control, Ministry of Health \& Welfare, and Republic of Korea (1420080). This research was supported by Basic Science Research Program through the National Research Foundation of Korea (NRF) funded by the Ministry of Science, ICT and Future Planning (2015R1A1A1A05001209).

\section{Availability of data and materials}

All data generated and analyzed during this study are included in this published article.

\section{Ethics approval and consent to participate}

This study was approved by the Institutional Review Board (IRB) of Yonsei University Severance Hospital. Informed consent form was waived by the IRB.

\section{Competing interests}

The authors declare that they have no competing interests.

\section{Consent for publication}

Not applicable.

\section{Author details \\ ${ }^{1}$ Department of Pathology, CHA Gangnam Medical Center, CHA University School of Medicine, Seoul, South Korea. ${ }^{2}$ Department of Pathology, Yonsei University College of Medicine, Severance Hospital, 50 Yonsei-ro, Seodae- mun-gu, Seoul 120-752, South Korea.}

Received: 6 December 2018 Accepted: 18 August 2019

Published online: 28 August 2019

\section{References}

1. Jansen S, Stefan C, Creemers JW, Waelkens E, Van Eynde A, Stalmans W, Bollen M. Proteolytic maturation and activation of autotaxin (NPP2), a secreted metastasis-enhancing lysophospholipase D. J Cell Sci. 2005;118:3081-9.
2. van Meeteren LA, Moolenaar WH. Regulation and biological activities of the autotaxin-LPA axis. Prog Lipid Res. 2007;46:145-60.

3. Choi JW, Herr DR, Noguchi K, Yung YC, Lee CW, Mutoh T, Lin ME, Teo ST, Park KE, Mosley AN, Chun J. LPA receptors: subtypes and biological actions. Annu Rev Pharmacol Toxicol. 2010;50:157-86.

4. Chun J, Hla T, Lynch KR, Spiegel S, Moolenaar WH. International union of basic and clinical pharmacology. LXXVIII. Lysophospholipid receptor nomenclature. Pharmacol Rev. 2010;62:579-87.

5. Houben AJ, Moolenaar WH. Autotaxin and LPA receptor signaling in cancer. Cancer Metastasis Rev. 2011;30:557-65.

6. Willier S, Butt E, Grunewald TG. Lysophosphatidic acid (LPA) signalling in cell migration and cancer invasion: a focussed review and analysis of LPA receptor gene expression on the basis of more than 1700 cancer microarrays. Biol Cell. 2013;105:317-33.

7. Kehlen A, Englert N, Seifert A, Klonisch T, Dralle H, Langner J, Hoang-Vu C. Expression, regulation and function of autotaxin in thyroid carcinomas. Int J Cancer. 2004;109:833-8.

8. Bryson PC, Shores CG, Hart C, Thorne L, Patel MR, Richey L, Farag A, Zanation AM. Immunohistochemical distinction of follicular thyroid adenomas and follicular carcinomas. Arch Otolaryngol Head Neck Surg. 2008;134:581-6.

9. Benesch MG, Ko YM, Tang X, Dewald J, Lopez-Campistrous A, Zhao YY, Lai R, Curtis JM, Brindley DN, McMullen TP. Autotaxin is an inflammatory mediator and therapeutic target in thyroid cancer. Endocr Relat Cancer. 2015;22:593-607.

10. Hassan AM, Alm El-Din MA, Nagy H, Ghoneem N, El-Heniedy MA, Koteb $\mathrm{N}, \mathrm{El}-\mathrm{Gohary} \mathrm{S}$. Significance of autotaxin activity and overexpression in comparison to soluble intercellular adhesion molecule in thyroid cancer. Int J Biol Markers. 2013;28:84-91.

11. Choi J, Jung WH, Koo JS. Clinicopathologic features of molecular subtypes of triple negative breast cancer based on immunohistochemical markers. Histol Histopathol. 2012;27:1481-93.

12. Azare J, Doane A, Leslie K, Chang Q, Berishaj M, Nnoli J, Mark K, AlAhmadie H, Gerald W, Hassimi M, Viale A, Stracke M, Lyden D, Bromberg J. Stat3 mediates expression of autotaxin in breast cancer. PLoS ONE. 2011;6:e27851.

13. Maliszewska A, Leandro-Garcia LJ, Castelblanco E, Macia A, de Cubas A, Gomez-Lopez G, Inglada-Perez L, Alvarez-Escola C, De la Vega L, Leton R, Gomez-Grana A, Landa I, Cascon A, Rodriguez-Antona C, Borrego S, Zane M, Schiavi F, Merante-Boschin I, Pelizzo MR, Pisano DG, Opocher G, Matias-Guiu X, Encinas M, Robledo M. Differential gene expression of medullary thyroid carcinoma reveals specific markers associated with genetic conditions. Am J Pathol. 2013;182:350-62.

14. Mancikova V, Montero-Conde C, Perales-Paton J, Fernandez A, Santacana M, Jodkowska K, Inglada-Perez L, Castelblanco E, Borrego S, Encinas M, Matias-Guiu X, Fraga M, Robledo M. Multilayer OMIC data in medullary thyroid carcinoma identifies the STAT3 pathway as a potential therapeutic target in RET(M918T) tumors. Clin Cancer Res. 2017;23:1334-45.

15. Schulte KM, Beyer A, Kohrer K, Oberhauser S, Roher HD. Lysophosphatidic acid, a novel lipid growth factor for human thyroid cells: over-expression of the high-affinity receptor edg4 in differentiated thyroid cancer. Int J Cancer. 2001;92:249-56.

16. Aust G, Eichler W, Laue S, Lehmann I, Heldin NE, Lotz O, Scherbaum WA Dralle H, Hoang-Vu C. CD97: a dedifferentiation marker in human thyroid carcinomas. Cancer Res. 1997;57:1798-806.

17. Ward Y, Lake R, Martin PL, Killian K, Salerno P, Wang T, Meltzer P, Merino M, Cheng SY, Santoro M, Garcia-Rostan G, Kelly K. CD97 amplifies LPA receptor signaling and promotes thyroid cancer progression in a mouse model. Oncogene. 2013;32:2726-38.

18. Whipple CA, Brinckerhoff CE. BRAF(V600E) melanoma cells secrete factors that activate stromal fibroblasts and enhance tumourigenicity. $\mathrm{Br} \mathrm{J}$ Cancer. 2014;111:1625-33.

19. Popnikolov NK, Dalwadi BH, Thomas JD, Johannes GJ, Imagawa WT. Association of autotaxin and lysophosphatidic acid receptor 3 with aggressiveness of human breast carcinoma. Tumour Biol. 2012;33:2237-43.

20. Nouh MA, Wu XX, Okazoe H, Tsunemori H, Haba R, Abou-Zeid AM, Saleem MD, Inui M, Sugimoto M, Aoki J, Kakehi Y. Expression of autotaxin and acylglycerol kinase in prostate cancer: association with cancer development and progression. Cancer Sci. 2009;100:1631-8.

21. Li M, Xiao D, Zhang J, Qu H, Yang Y, Yan Y, Liu X, Wang J, Liu L, Wang J, Duan $X$. Expression of LPA2 is associated with poor prognosis in human 
breast cancer and regulates HIF-1alpha expression and breast cancer cell growth. Oncol Rep. 2016;36:3479-87.

22. Boucharaba A, Serre CM, Gres S, Saulnier-Blache JS, Bordet JC, Guglielmi J, Clezardin P, Peyruchaud O. Platelet-derived lysophosphatidic acid supports the progression of osteolytic bone metastases in breast cancer. J Clin Invest. 2004;114:1714-25.

23. David M, Ribeiro J, Descotes F, Serre CM, Barbier M, Murone M, Clezardin P, Peyruchaud O. Targeting lysophosphatidic acid receptor type 1 with Debio 0719 inhibits spontaneous metastasis dissemination of breast cancer cells independently of cell proliferation and angiogenesis. Int J Oncol. 2012;40:1133-41.

24. Marshall JC, Collins JW, Nakayama J, Horak CE, Liewehr DJ, Steinberg SM, Albaugh M, Vidal-Vanaclocha F, Palmieri D, Barbier M, Murone M, Steeg PS. Effect of inhibition of the lysophosphatidic acid receptor 1 on metastasis and metastatic dormancy in breast cancer. J Natl Cancer Inst. 2012;104:1306-19.
25. Zhang H, Xu X, Gajewiak J, Tsukahara R, Fujiwara Y, Liu J, Fells JI, Perygin D, Parrill AL, Tigyi G, Prestwich GD. Dual activity lysophosphatidic acid receptor pan-antagonist/autotaxin inhibitor reduces breast cancer cell migration in vitro and causes tumor regression in vivo. Cancer Res. 2009;69:5441-9.

\section{Publisher's Note}

Springer Nature remains neutral with regard to jurisdictional claims in published maps and institutional affiliations.
Ready to submit your research? Choose BMC and benefit from:

- fast, convenient online submission

- thorough peer review by experienced researchers in your field

- rapid publication on acceptance

- support for research data, including large and complex data types

- gold Open Access which fosters wider collaboration and increased citations

- maximum visibility for your research: over 100M website views per year

At BMC, research is always in progress.

Learn more biomedcentral.com/submissions 